\title{
Use of organic solvents in large research institutions in Japan
}

\author{
Yasuhiro Nagasawa $\cdot$ Hajime Samoto $\cdot$ Hirohiko Ukai $\cdot$ Satoru Okamoto $\cdot$ Kenji Itoh $\cdot$ \\ Takaki Hanada $\cdot$ Ai Kanemaru $\cdot$ Yoshinari Fukui $\cdot$ Satoshi Kojima $\cdot$ Jiro Moriguchi \\ Sonoko Sakuragi $\cdot$ Fumiko Ohashi $\cdot$ Shiro Takada $\cdot$ Takuya Kawakami $\cdot$ Masayuki Ikeda
}

Received: 1 October 2012/ Accepted: 11 December 2012/Published online: 13 February 2013

(C) The Japanese Society for Hygiene 2013

\begin{abstract}
Objectives Laboratories in research institutions use organic solvents in research and development. Nevertheless, the types of solvents in use have been seldom reported. This study was initiated to elucidate types of organic solvents used in large research institutions in Japan, with a focus on possible different use among research fields.

Methods In 2010-2011, 4517 laboratories in seven large research institutions were visited. In accordance with legal stipulations, air in each laboratory was collected in polyvinyl fluoride bags and analyzed by direct injection into a gas-chromatograph for 47 types of organic solvents. In evaluation, the laboratories were grouped by 5 research fields, i.e., agriculture, biology, medicine, natural science, and technology and engineering.

Results Types of organic solvents commonly used in research activities were not diverse. Those commonly used were chloroform and 1,2-dichloroethane out of 7 Group 1 organic solvents (with high toxicities); 6 organic solvents, i.e., acetone and methyl alcohol in general, ethyl acetate, hexane and toluene in technology and engineering laboratories; and xylenes in medical fields out of 40 Group 2 organic solvents (with relatively low toxicities). Judging from solvent vapor concentrations, work environments in
\end{abstract}

Y. Nagasawa $\cdot$ H. Samoto $\cdot$ H. Ukai $\cdot$ S. Okamoto $\cdot$ K. Itoh $\cdot$

T. Hanada - A. Kanemaru - Y. Fukui - S. Kojima - F. Ohashi ·

S. Takada $\cdot$ T. Kawakami $\cdot$ M. Ikeda $(\bowtie)$

Kyoto Industrial Health Association (Main Office),

67 Nishinokyo-Kitatsuboicho, Nakagyo-ku,

Kyoto 604-8472, Japan

e-mail: ikeda@hokenkai.jp

J. Moriguchi · S. Sakuragi

Kyoto Industrial Association (Mibu Office),

4-1 Mibu-Shujaku-cho, Nakagyo-ku, Kyoto 604-8871, Japan more than $99 \%$ of laboratories were considered adequate. Nevertheless, use of chloroform in high-performance liquid chromatography (HPLC) resulted in inadequate environments in 30 laboratories $(0.7 \%)$.

Conclusions Organic solvents commonly used were not very diverse. Work environments in research laboratories were generally good, but the environment with use of chloroform in HPLC analysis remained yet to be improved.

Keywords Chloroform · Organic solvents · Research laboratory $\cdot$ Unmixed solvents $\cdot$ Xylenes

\section{Introduction}

Under Industrial Safety and Health Law [1, 2], administrations of national and public research institutions (including universities) in Japan are responsible for maintenance of healthy environment. For this purpose, the law stipulates that the environment in workrooms including research laboratories should be monitored in accordance with procedures legally defined $[3,4]$. The enforcement has produced a valuable opportunity so that the exposure to chemicals in research institution laboratories should be monitored and improvement should be conducted when the exposure does not meet with the legal standards.

Organic solvents are among the chemicals widely used in many laboratories across various fields of natural sciences. Nevertheless, information on the solvent use has been reported only on limited occasions and usually as a simple compilation of solvent names [5-10] with no further details such as use prevalence. In the present study, seven large research institutions were studied for solvent use in laboratories. Efforts were made to identify characteristic (if any) solvent types subject to the fields of science. A preliminary 
Table 1 Organic solvents registered in the Regulations for Prevention of Organic Solvent Poisoning, and Administrative Control Levels for each solvent

\begin{tabular}{|c|c|c|}
\hline Groups & Solvents & $\mathrm{ACL}^{\mathrm{a}}$ \\
\hline \multicolumn{3}{|c|}{ Group 1 organic solvents ( 7 solvents) } \\
\hline & Carbon disulfide & 1 \\
\hline & Carbon tetrachloride & 5 \\
\hline & Chloroform & 3 \\
\hline & 1,2-Dichloroethane (etylene dichloride) & 10 \\
\hline & 1,2-Dichloroethylene (acetylene dichloride) & 150 \\
\hline & 1,1,2,2-Tetrachloroethane (acetylene tetrachloride) & 1 \\
\hline & Trichloroethylene & 10 \\
\hline
\end{tabular}

Group 2 organic solvents (40 solvents)

\begin{tabular}{|c|c|}
\hline Acetone & 500 \\
\hline 1-Butanol & 25 \\
\hline 2-Butanol & 100 \\
\hline$n$-Butyl acetate & 150 \\
\hline Chlorobenzene & 10 \\
\hline Cresol & 5 \\
\hline Cyclohexanol & 25 \\
\hline Cyclohexanone & 20 \\
\hline$o$-Dichlorobenzene & 25 \\
\hline Dichloromethane (methylene dichloride) & 50 \\
\hline$N, N$-Dimethylformamide & 10 \\
\hline 1,4-Dioxane & 10 \\
\hline Ethyl acetate & 200 \\
\hline Ethyl ether & 400 \\
\hline $\begin{array}{l}\text { Ethylene glycol mono- } n \text {-butyl ether } \\
\text { (butyl cellosolve) }\end{array}$ & 25 \\
\hline Ethylene glycol monoethyl ether (cellosolve) & 5 \\
\hline $\begin{array}{l}\text { Ethylene glycol monoethyl ether acetate } \\
\text { (cellosolve acetate) }\end{array}$ & 5 \\
\hline $\begin{array}{l}\text { Ethylene glycol monomethyl ether } \\
\text { (methyl cellosolve) }\end{array}$ & 0 \\
\hline Hexane ( $n$-hexane) & 40 \\
\hline Isobutyl acetate & 150 \\
\hline Isobutyl alcohol & 50 \\
\hline Isopentyl acetate (isoamyl acetate) & 50 \\
\hline Isopentyl alcohol (isoamyl alcohol) & 100 \\
\hline Isopropyl acetate & 100 \\
\hline Isopropyl alcohol & 200 \\
\hline Methyl alcohol & 200 \\
\hline Methyl $n$-butyl ketone & 5 \\
\hline Methyl acetate & 200 \\
\hline Methyl ethyl ketone & 200 \\
\hline Methyl isobutyl ketone & 20 \\
\hline Methylcyclohexanol & 50 \\
\hline Methylcyclohexanone & 50 \\
\hline$n$-Pentyl acetate ( $n$-amyl acetate) & 50 \\
\hline$n$-Propyl acetate & 200 \\
\hline Styrene & 20 \\
\hline
\end{tabular}

Table 1 continued

\begin{tabular}{|c|c|c|}
\hline Groups & Solvents & $\mathrm{ACL}^{\mathrm{a}}$ \\
\hline & Tetrachloroethylene (perchloroethylene) & 50 \\
\hline & Tetrahydrofuran & 50 \\
\hline & Toluene & 20 \\
\hline & 1,1,1-Trichloroethane & 200 \\
\hline & Xylenes & 50 \\
\hline \multicolumn{3}{|c|}{ Group 3 organic solvents ( 7 solvents) } \\
\hline & \multicolumn{2}{|l|}{ Coal tar naphtha } \\
\hline & \multicolumn{2}{|l|}{$\begin{array}{l}\text { Mineral spirit (including mineral thinner, } \\
\text { mineral turpentine oil, petroleum spirit } \\
\text { and white spirit) }\end{array}$} \\
\hline & \multicolumn{2}{|l|}{ Petroleum benzine } \\
\hline & \multicolumn{2}{|l|}{ Petroleum ether } \\
\hline & \multicolumn{2}{|l|}{ Petroleum naphtha } \\
\hline & Turpentine oil & \\
\hline Mixtures & of only these solvents & \\
\hline
\end{tabular}

a ACL Administrative Control Level (in ppm; for details including definition, see the Materials and methods section

report based on a small-scale survey was previously published [11]. The results of surveys in succeeding years on an expanded scale will be presented in this article.

\section{Materials and methods}

Laboratories and organic solvents surveyed

Seven large institutions were surveyed during the 1-year period from 1 October 2010 until 31 September 2011. In total, 4517 laboratories were visited. A laboratory was typically in the size of $4 \mathrm{~m} \times 6 \mathrm{~m}$ with about $3 \mathrm{~m}$ to the ceiling, and usually accommodated 1-2 researchers. Some laboratories were, however, larger in size to accommodate up to 30 people, e.g., for the practice of post-graduate students. According to scientific research fields, the laboratories were classified into five groups, i.e., agricultural sciences (to be abbreviated as AGR), biological sciences (BIOL; excluding medicine), medicine (MED), natural sciences (SCI excluding AGR, BIOL and MED) and technology and engineering (T\&E), although there were several borderline cases.

The Order [3] and the Ordinance [12] define the types of organic solvents to be analyzed. Namely, 7 solvents of high toxicity are defined as Group 1 solvents, and another 40 solvents of relatively low toxicity are defined as Group 2 solvents (Table 1). In addition, the Order and the Ordinance identify 7 solvents (mostly of petroleum origin) as Group 3 solvents, but these 7 solvents were not taken in this analysis because they are mixtures by nature of poorly defined multiple organic solvents, not fit for quantification by gas-chromatography. Benzene, the most popular solvent 
in the past, is regulated under separate ordinance [13] because this solvent is a human leukemogen [14-17], and excluded from the present survey.

Sampling of laboratory air, analyses for organic solvents, and evaluation

The protocol for solvent vapor measurement was as previously detailed [18]. In short, $10 \mathrm{~L}$ of air was sampled in polyvinyl fluoride bags at 5 or more crosses of a hypothetical grid (with, e.g., up to $3 \mathrm{~m}$ apart between 2 grid lines) set in each laboratory as defined by regulation [3, 19]. It should be added that air sampling was conducted when the research activities were actually on. The air samples in the bags were brought to the laboratory in Kyoto Industrial Health Association and were analyzed by direct injection into FID-gaschromatography instruments equipped with a 25-m-long capillary column (for qualification purpose) or on a 2.5-m-long packed column (for quantification) [18].

The results of analysis for solvent vapor concentrations $(n \geq 5)$ were calculated for geometric means (GMs) and geometric standard deviations (GSDs) as representative parameters, and the parameters were evaluated in reference to Administrative Control Levels (ACLs [4]; for ACL value of each organic solvent, see Table 1) to classify the cases into 3 classes of Administrative Control Class 1 (the well-controlled environment), Class 2 (the environment that needs further improvements) and Class 3 (the environment which requires immediate and sufficient improvement [4]) after the following equations:

Class 1 when $\log \mathrm{ACL}>\log \mathrm{GM}+1.645\left[(\log \mathrm{GM})^{2}+\right.$ $0.084]^{1 / 2}$

Class 3 when $\log$ ACL $<\log \mathrm{GM}+1.151\left[(\log \mathrm{GM})^{2}+\right.$ $0.084]$, and

Class 2 between the 2 levels.

By definition, 5 and $50 \%$ of the organic solvent concentrations in the workroom air would exceed ACL in Class 2 and Class 3, respectively. The regulation [4] requests repeated measurements on 2 consecutive days, and a constant of 0.084 was empirically added for the cases of 1-day measurement to make the conditions more strict [20]. It should be noted that the visit to each laboratory was on 1 day in the present study. In case more than 2 solvents were detected, the additiveness formula of $\Sigma M_{i} / \mathrm{ACL}_{i}$ (where $M_{i}$ and $\mathrm{ACL}_{i}$ are measured concentration and ACL for solvent $i$, respectively) was employed in place of measure for an individual solvent [4].

\section{Statistical analyses}

Chi square test was employed to detect possible significant difference in distribution; $p<0.01$ was taken as a cut-off point for statistical significance. When the number of cases in a cell was five or less, $\chi^{2}$ test was considered not applicable. Such cases were identified as 'na' in the tables.

\section{Results}

Number of laboratories as classified by research fields, and solvent use

When a total of 4517 laboratories were grouped by the five research fields of AGR, BIOL, MED, SCI and T\&E, the numbers of laboratories in MED, SCI and T\&E were in excess of 1000, whereas those in AGR and BIOL were around 600 (Table 2). Each of the laboratories in the five research fields were further classified by the groups of organic solvents used, i.e., those with Group 1 solvents only, those with Group 2 solvents only, and those with Group 1 and 2 solvents together. In addition, those with Group 1 solvents were counted irrespective of the use of Group 2 solvents in combination (Table 2).

It turned out that, over all, the use of Group 1 solvents was in less than $10 \%$ of total laboratories (i.e., 9.6\%) whereas the use of Group 2 solvents only was common (74\%). When evaluated by research fields, the use of Group 1 solvents only were less prevalent in SCI and T\&E laboratories $(169 / 2242=7.5 \%$; two research fields of the

Table 2 Number of laboratories where Group 1 and Group 2 organic solvents were in use

\begin{tabular}{|c|c|c|c|c|c|c|c|c|c|c|c|c|}
\hline & \multicolumn{2}{|c|}{ AGR } & \multicolumn{2}{|c|}{ BIOL } & \multicolumn{2}{|l|}{ MED } & \multicolumn{2}{|l|}{ SCI } & \multicolumn{2}{|l|}{$T \& E$} & \multicolumn{2}{|l|}{ Total } \\
\hline & $n$ & $(\%)$ & $n$ & $(\%)$ & $n$ & $(\%)$ & $n$ & $(\%)$ & $n$ & $(\%)$ & $n$ & $(\%)$ \\
\hline Group 1 organic solvents only & 80 & $(13.5)$ & 60 & $(9.0)$ & 125 & $(12.3)$ & 83 & (7.6) & 86 & $(7.5)$ & 434 & (9.6) \\
\hline Group 2 organic solvents only & 390 & $(65.7)$ & 461 & $(69.4)$ & 731 & (71.9) & 941 & $(86.4)$ & 803 & $(69.6)$ & 3326 & $(73.6)$ \\
\hline Both Group 1 and Group 2 organic solvents & 124 & $(20.9)$ & 143 & $(21.5)$ & 161 & $(15.8)$ & 65 & $(6.0)$ & 264 & $(22.9)$ & 757 & $(16.8)$ \\
\hline Group 1 with or without Group 2 organic solvents & 204 & $(34.3)$ & 203 & $(30.6)$ & 286 & $(28.1)$ & 148 & $(13.6)$ & 350 & $(30.4)$ & 1191 & $(26.4)$ \\
\hline Total $^{\mathrm{a}}$ & 594 & $(100)$ & 664 & $(100)$ & 1017 & $(100)$ & 1089 & $(100)$ & 1153 & $(100)$ & 4517 & $(100)$ \\
\hline
\end{tabular}

${ }^{a}$ Some laboratories used more than one type of Group 1 organic solvent 
lowest prevalence) than in others (i.e., AGR + BIOL + MED; $265 / 2275=11.6 \%: p<0.01$ by $\chi^{2}$ test) whereas the use of Group 2 solvent was more prevalent in SCI laboratories $(941 / 1089=86.4 \%$; the research field of the highest prevalence) than in others (i.e., AGR + BIOL + MED + T\&E, 2385/3428 = 69.6\%: $p<0.01$ by $\chi^{2}$ test). Similarly, the use of Group 1 solvents with or without Group 2 solvents was significantly less prevalent in SCI laboratories $(148 / 1089=13.6 \%$; the least prevalent $)$ than in other fields (i.e., AGR + BIOL + MED + T\&E, $1043 / 3428=30.4 \% ; p<0.01$ by $\chi^{2}$ test $)$.
Typical use of organic solvents in research laboratories was as a single, unmixed solvent (Fig. 1). Observation of practice in laboratories showed that each researcher used one solvent in one process. When 2 or more types of organic solvents were detected in laboratory air, it was usually as the results of 2 or more researchers working with different solvents in one room, or one researcher used 2 or more different types of solvents in sequence. Typical cases were observed in large $T \& E$ laboratories for practice of undergraduate students where multiple solvents were detected.
Fig. 1 Number of types of organic solvents detected in laboratories of various fields of science The left-most five columns for each solvent number group are (from left to right) for agriculture (AGR), biology (BIOL), medicine (MED), natural science (SCI), and technology and engineering (T\&E). The right-most thick columns are for use in enterprises (cited from Ref. [18]). Note that cases with $8-13$ solvents are summed up

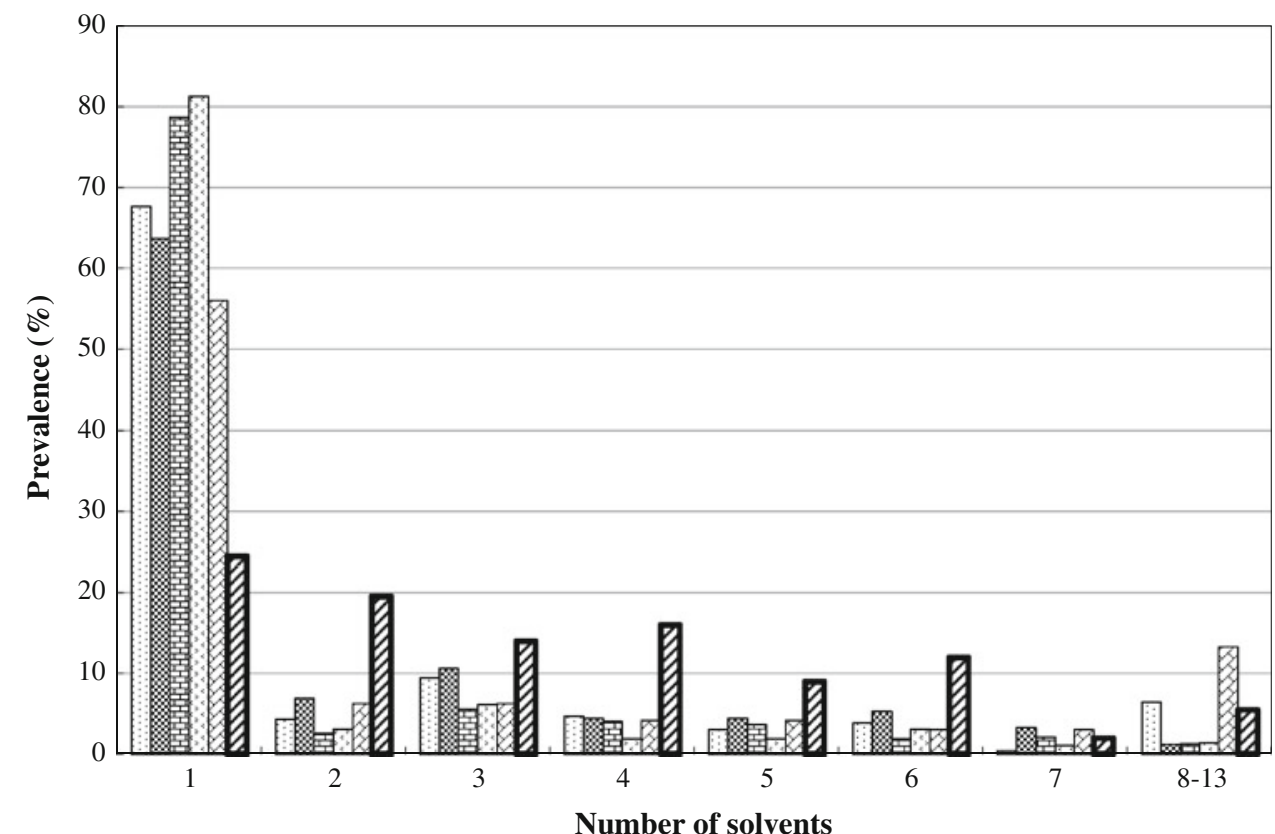

Table 3 Group 1 solvents detected in laboratory air, as classified by research fields

\begin{tabular}{|c|c|c|c|c|c|c|c|c|c|}
\hline \multirow[t]{2}{*}{ Group 1 solvents $^{\mathrm{a}}$} & \multicolumn{6}{|c|}{ Research fields } & \multicolumn{3}{|l|}{$p$ by $\chi^{2}$ test } \\
\hline & AGR & $\mathrm{BIOL}$ & MED & SCI & $\mathrm{T} \& \mathrm{E}$ & Total & $\begin{array}{l}\text { Biological vs. } \\
\text { chemical }^{c^{c}}\end{array}$ & $\begin{array}{l}\text { AGR vs. } \\
\text { others }^{\mathrm{d}}\end{array}$ & $\begin{array}{l}\text { T\&E vs. } \\
\text { others }\end{array}$ \\
\hline No. of laboratories surveyed & 594 & 664 & 1017 & 1089 & 1153 & 4517 & & & \\
\hline Carbon disulfide $(\%)^{\mathrm{b}}$ & $0(0.0)$ & $5(0.8)$ & $0(0.0)$ & $0(0.0)$ & $0(0.0)$ & $5(0.1)$ & $\mathrm{na}^{\mathrm{f}}$ & $\mathrm{na}^{\mathrm{f}}$ & $\mathrm{na}^{\mathrm{f}}$ \\
\hline Carbon tetrachloride $(\%)^{\mathrm{b}}$ & $2(0.3)$ & $9(1.4)$ & $2(0.2)$ & $2(0.2)$ & $12(1.0)$ & $27(0.6)$ & ns & $\mathrm{na}^{\mathrm{f}}$ & $<0.05$ \\
\hline Chloroform $(\%)^{\mathrm{b}}$ & $203(34.2)$ & $183(27.6)$ & $285(28.0)$ & $143(13.1)$ & $337(29.2)$ & $1151(25.5)$ & $<0.01$ & $<0.01$ & $<0.01$ \\
\hline 1,2-Dichloroethane $(\%)^{\mathrm{b}}$ & $4(0.7)$ & $10(1.5)$ & $1(0.1)$ & $4(0.4)$ & $43(3.7)$ & $62(1.4)$ & $<0.01$ & $\mathrm{na}^{\mathrm{f}}$ & $<0.01$ \\
\hline Trichloroethylene $(\%)^{\mathrm{b}}$ & $0(0.0)$ & $2(0.3)$ & $0(0.0)$ & $0(0.0)$ & $3(0.3)$ & $5(0.1)$ & $n a^{\mathrm{f}}$ & $n a^{\mathrm{f}}$ & $\mathrm{na}^{\mathrm{f}}$ \\
\hline $\operatorname{Sum}(\%)^{\mathrm{b}}$ & $209(35.2)$ & $209(31.5)$ & $288(28.3)$ & 149 (13.7) & $395(34.3)$ & $1250(27.6)$ & & & \\
\hline
\end{tabular}

a Two solvents, 1,2-dichloroethylene and 1,1,2,2-tetrachloroethane, were not detected

${ }^{b}$ Percentage over the numbers of laboratories surveyed

${ }^{c}$ Comparison between biological (AGR + BIOL + MED) laboratories versus. chemical (SCI + T\&E) laboratories; ns for $p>0.05$

${ }^{\mathrm{d}}$ Comparison between AGR laboratories versus other 4 groups (i.e., BIOL $+\mathrm{MED}+\mathrm{SCI}+\mathrm{T} \& \mathrm{E}$ )

${ }^{\mathrm{e}}$ Comparison between T\&E laboratories versus other 4 groups (i.e., AGR + BIOL + MED + SCI)

${ }^{\mathrm{f}} \mathrm{na}, \chi^{2}$ test is not applicable, because the number in a cell (or some cells) is less than five 
Group 1 solvents frequently used

The names of 5 Group 1 solvents actually detected (out of a total of 7) are listed in Table 3; the other 2 Group 1 solvents (i.e., 1,2-dichloroehylene and 1,1,2,2-tetrachloroethane) were never detected as to be described later. Among the 5 solvents, chloroform had a high prevalence $(26 \%)$, being highest in AGR laboratories (34\%; $p<0.01$ for difference from others) but was also high in T\&E laboratories $(29 \% ; p<0.01)$ and in other fields in general $(>13 \%)$. The typical use was as a component in the mobile phase in high-pressure liquid chromatography (HPLC). Very often, the HPLC instrument was too bulky to be accommodated in a local exhaust chamber. The second most common was the use of 1,2-dichloroethane, being highest in T\&E $(3.7 \% ; p<0.01)$ among the 5 fields. It was not possible to identify specific use of this solvent.

Use pattern of Group 2 solvents

The use prevalence of the 40 Group 2 organic solvents is summarized in Table 4. Among 40 Group 2 organic solvents, acetone and methyl alcohol were most often used throughout all fields $(>30 \%)$ and in T\&E in particular (48\% for acetone and $35 \%$ for methyl alcohol in T\&E). The major use was for rapid drying of an inside wall of a

Table 4 Group 2 solvents detected in laboratory air, as classified by research fields

\begin{tabular}{|c|c|c|c|c|c|c|c|}
\hline \multirow[t]{2}{*}{ Group 2 solvents } & \multicolumn{6}{|c|}{ Research fields } & \multirow[t]{2}{*}{$p$ by $\chi^{2}$ test } \\
\hline & AGR & BIOL & MED & SCI & $\mathrm{T} \& \mathrm{E}$ & Total & \\
\hline No. of laboratories surveyed & 594 & 664 & 1017 & 1089 & 1153 & 4517 & \\
\hline Acetone $(\%)^{\mathrm{a}}$ & $123(20.7)$ & $172(25.9)$ & $185(18.2)$ & $328(30.1)$ & $555(48.1)$ & $1363(30.2)$ & $<0.01$ \\
\hline 1-Butanol $(\%)^{\mathrm{a}}$ & $34(6.3)$ & $30(4.5)$ & $34(3.3)$ & $16(1.5)$ & $24(2.1)$ & $138(3.1)$ & $<0.01$ \\
\hline 2-Butanol $(\%)^{\mathrm{a}}$ & $0(0.0)$ & $1(0.2)$ & $6(0.6)$ & $7(0.6)$ & $6(0.5)$ & $20(0.4)$ & na \\
\hline$n$-Butyl acetate $(\%)^{\mathrm{a}}$ & $0(0.0)$ & $3(0.5)$ & $0(0.0)$ & $2(0.2)$ & $2(0.2)$ & $7(0.2)$ & na \\
\hline Chlorobenzene $(\%)^{\mathrm{a}}$ & $0(0.0)$ & $5(0.8)$ & $0(0.0)$ & $6(0.6)$ & $10(0.9)$ & $21(0.5)$ & na \\
\hline $\operatorname{Cresol}(\%)^{\mathrm{a}}$ & $1(0.2)$ & $1(0.2)$ & $2(0.2)$ & $6(0.6)$ & $0(0.0)$ & $10(0.2)$ & na \\
\hline Cyclohexanol $(\%)^{\mathrm{a}}$ & $0(0.0)$ & $0(0.0)$ & $0(0.0)$ & $0(0.0)$ & $3(0.3)$ & $3(0.1)$ & na \\
\hline Cyclohexanone $(\%)^{\mathrm{a}}$ & $0(0.0)$ & $0(0.0)$ & $0(0.0)$ & $2(0.2)$ & $3(0.3)$ & $5(0.1)$ & na \\
\hline$o$-Dichlorobenzene $(\%)^{\mathrm{a}}$ & $0(0.0)$ & $0(0.0)$ & $0(0.0)$ & $0(0.0)$ & $3(0.3)$ & $3(0.1)$ & na \\
\hline Dichloromethane $(\%)^{\mathrm{a}}$ & $33(5.6)$ & $26(3.9)$ & $17(1.7)$ & $111(10.2)$ & $187(16.2)$ & $374(8.3)$ & $<0.01$ \\
\hline$N, N$-Dimethylformamide $(\%)^{\mathrm{a}}$ & $34(5.7)$ & $58(8.7)$ & $57(5.6)$ & $46(4.2)$ & $64(5.6)$ & $259(5.7)$ & $<0.01$ \\
\hline 1,4-Dioxane $(\%)^{\mathrm{a}}$ & $6(1.0)$ & $3(0.5)$ & $3(0.3)$ & $2(0.2)$ & $10(0.9)$ & $24(0.5)$ & na \\
\hline EG monoethyl ether $(\%)^{\mathrm{a}}$ & $0(0.0)$ & $0(0.0)$ & $0(0.0)$ & $1(0.1)$ & $0(0.0)$ & $1(0.0)$ & na \\
\hline EG monomethyl ether $(\%)^{\mathrm{a}}$ & $0(0.0)$ & $0(0.0)$ & $0(0.0)$ & $4(0.4)$ & $0(0.0)$ & $4(0.1)$ & na \\
\hline Ethyl acetate $(\%)^{\mathrm{a}}$ & $85(14.3)$ & $46(6.9)$ & $31(3.0)$ & $99(9.1)$ & $245(21.2)$ & $506(11.2)$ & $<0.01$ \\
\hline Ethyl ether $(\%)^{\mathrm{a}}$ & $80(13.5)$ & $83(12.5)$ & $156(15.3)$ & $69(6.3)$ & $140(12.1)$ & $528(11.7)$ & $<0.01$ \\
\hline Hexane $(\%)^{\mathrm{a}}$ & $68(11.4)$ & $65(9.8)$ & $50(4.9)$ & $112(10.3)$ & $314(27.2)$ & $609(13.5)$ & $<0.01$ \\
\hline Isobutyl alcohol $(\%)^{\mathrm{a}}$ & $4(0.7)$ & $5(0.8)$ & $1(0.1)$ & $4(0.4)$ & $3(0.3)$ & $17(0.4)$ & na \\
\hline Isopentyl acetate $(\%)^{\mathrm{a}}$ & $4(0.7)$ & $2(0.3)$ & $0(0.0)$ & $0(0.0)$ & $0(0.0)$ & $6(0.1)$ & na \\
\hline Isopentyl alcohol $(\%)^{\mathrm{a}}$ & $26(4.4)$ & $3(0.5)$ & $14(1.4)$ & $15(1.4)$ & $1(0.1)$ & $59(1.3)$ & na \\
\hline Isopropyl alcohol $(\%)^{\mathrm{a}}$ & $139(23.4)$ & $155(23.3)$ & $249(24.5)$ & $136(12.5)$ & $155(13.4)$ & $834(18.5)$ & $<0.01$ \\
\hline Methyl acetate $(\%)^{\mathrm{a}}$ & $2(0.3)$ & $8(1.2)$ & $2(0.2)$ & $3(0.3)$ & $3(0.3)$ & $18(0.4)$ & na \\
\hline Methyl alcohol $(\%)^{\mathrm{a}}$ & $215(36.2)$ & $258(38.9)$ & $348(34.2)$ & $272(25.0)$ & $403(35.0)$ & $1496(33.1)$ & $<0.01$ \\
\hline Methyl ethyl ketone $(\%)^{\mathrm{a}}$ & $0(0.0)$ & $0(0.0)$ & $0(0.0)$ & $8(0.7)$ & $8(0.7)$ & $16(0.4)$ & na \\
\hline Methyl isobutyl ketone $(\%)^{\mathrm{a}}$ & $0(0.0)$ & $0(0.0)$ & $0(0.0)$ & $1(0.1)$ & $4(0.3)$ & $5(0.1)$ & na \\
\hline Styrene $(\%)^{\mathrm{a}}$ & $0(0.0)$ & $3(0.5)$ & $0(0.0)$ & $1(0.1)$ & $10(0.9)$ & $14(0.3)$ & na \\
\hline Tetrahydrofuran $(\%)^{\mathrm{a}}$ & $27(4.5)$ & $22(3.3)$ & $7(0.7)$ & $18(1.7)$ & $146(12.7)$ & $220(4.9)$ & $<0.01$ \\
\hline Toluene $(\%)^{\mathrm{a}}$ & $44(7.4)$ & $36(5.4)$ & $32(3.1)$ & $56(5.1)$ & $236(20.5)$ & $404(8.9)$ & $<0.01$ \\
\hline Xylenes $(\%)^{\mathrm{a}}$ & $40(6.7)$ & $51(7.7)$ & $235(23.1)$ & $54(5.0)$ & $79(6.9)$ & $459(10.2)$ & $<0.01$ \\
\hline
\end{tabular}

EG Ethylene glycol

na, $\chi^{2}$ test is not applicable, because the number in a cell (or some cells) is less than 5

${ }^{\text {a }}$ Percentage over the number of laboratories surveyed 
Table 5 Solvents seldom detected in laboratories

\begin{tabular}{|c|c|c|c|}
\hline Groups & Solvent names & $\begin{array}{l}\text { No of } \\
\text { cases }\end{array}$ & $\begin{array}{l}\text { Prevalence } \\
(\%)^{\mathrm{a}}\end{array}$ \\
\hline \multicolumn{4}{|c|}{ Solvents which were not detected in laboratory } \\
\hline \multirow[t]{2}{*}{ Group 1} & $\begin{array}{l}\text { 1,2-Dichloroethylene (acetylene } \\
\text { dichloride) }\end{array}$ & 0 & \\
\hline & $\begin{array}{l}\text { 1,1,2,2-Tetrachloroethane (acetylene } \\
\text { tetrachloride) }\end{array}$ & 0 & \\
\hline \multirow[t]{11}{*}{ Group 2} & $\begin{array}{l}\text { Ethylene glycol monoethyl ether } \\
\text { acetate (cellosolve acetate) }\end{array}$ & 0 & \\
\hline & $\begin{array}{l}\text { Ethylene glycol mono- } n \text {-butyl } \\
\text { ether (butyl cellosolve) }\end{array}$ & 0 & \\
\hline & Isobutyl acetate & 0 & \\
\hline & Isopropyl acetate & 0 & \\
\hline & Methyl $n$-butyl ketone & 0 & \\
\hline & Methylcyclohexanol & 0 & \\
\hline & Methylcyclohexanone & 0 & \\
\hline & $n$-Pentyl acetate ( $n$-amyl acetate) & 0 & \\
\hline & $n$-Propyl acetate & 0 & \\
\hline & $\begin{array}{l}\text { Tetrachloroethylene } \\
\text { (perchloroethylene) }\end{array}$ & 0 & \\
\hline & 1,1,1-Trichloroethane & 0 & \\
\hline \multicolumn{4}{|c|}{ Solvents which were detected in less than $1 \%$ of laboratories } \\
\hline \multirow[t]{3}{*}{ Group 1} & Carbon disulfide & 5 & 0.11 \\
\hline & Trichloroethylene & 5 & 0.11 \\
\hline & Carbon tetrachloride & 27 & 0.60 \\
\hline \multirow[t]{15}{*}{ Group 2} & $\begin{array}{l}\text { Ethylene glycol monoethyl ether } \\
\text { (cellosolve) }\end{array}$ & 1 & 0.02 \\
\hline & Cyclohexanol & 3 & 0.07 \\
\hline & $o$-Dichlorobenzene & 3 & 0.07 \\
\hline & $\begin{array}{l}\text { Ethylene glycol monomethyl ether } \\
\text { (methyl cellosolve) }\end{array}$ & 4 & 0.09 \\
\hline & Methyl isobutyl ketone & 5 & 0.11 \\
\hline & Cyclohexanone & 5 & 0.11 \\
\hline & $n$-Butyl acetate & 7 & 0.15 \\
\hline & Cresol & 10 & 0.22 \\
\hline & Styrene & 14 & 0.31 \\
\hline & Methyl ethyl ketone & 16 & 0.35 \\
\hline & Isobutyl alcohol & 17 & 0.38 \\
\hline & Methyl acetate & 18 & 0.40 \\
\hline & Chlorobenzene & 21 & 0.46 \\
\hline & 1,4-Dioxane & 24 & 0.53 \\
\hline & 2-Butanol & 20 & 0.44 \\
\hline
\end{tabular}

${ }^{a}$ Out of 4517 laboratries surveyed

glass or plastic container. In addition, methyl alcohol was a common component of a mobile phase in HPLC analysis. Dichloromethane was used in T\&E (16\%) for extraction purpose. Ethyl acetate $(21 \%)$, hexane $(27 \%)$ and toluene $(21 \%)$ were also often used in T\&E, but no specific use could be identified. In contrast, the frequent use of xylenes in MED (23\%) was unique as this solvent was specifically used for removal of paraffin in the process of histology specimen preparation.
Solvents of limited use in laboratories

Among the 7 Group 1 and 40 Group 2 solvents, some solvents were not detected or detected only on limited occasions. They are listed in Table 5. It was made clear that 2 Group 1 solvents and 11 Group 2 solvents were never detected in laboratory air (the top half in Table 5). In addition, 3 Group 1 and 15 Group 2 solvents were found only rarely (i.e., in the prevalence of less than $1 \%$; the bottom half in Table 5).

\section{Distribution of Class 2 and Class 3 environments}

When classified in terms of adequate (Class 1) and inadequate (Class 2 and Class 3) work environments, it was evident that, over all, a majority ( $>99 \%)$ of laboratories were in Class 1 irrespective of research fields (Table 6). Nevertheless the environments in 32 laboratories in total were identified as inadequate, i.e., Class 2 or Class 3. Further breakdown of the cases revealed that the Classes 2 and 3 prevalence was significantly $(p<0.01)$ higher in $\mathrm{T} \& \mathrm{E}(1.7 \%)$ as compared with other fields $(0.4 \%)$ (the top two-thirds in Table 6), whereas no significant difference was observed between biological and chemical laboratories $(p>0.10)$ (the bottom one-third in Table 6).

Perusal of the records for each laboratory disclosed that chloroform was detected in 30 cases out of 32 Class 2 and Class 3 laboratories, either as the only one solvent or in copresence of other solvents. In remaining 2 laboratories, high concentration of hexane (Class 3 laboratory) or dichloromethane (Class 2) was detected as a sole solvent.

\section{Discussion}

The present survey disclosed that types of solvents commonly used in research laboratories appear to be not very diverse, being only 2 Group 1 solvents (i.e., chloroform and, to a lesser extent, 1,2-dichloroethane; Table 3) and a few Group 2 solvents (acetone and methyl alcohol in general, and ethyl acetate, hexane, and toluene in T\&E, and xylenes in MED in particular; Table 4). With regard to use pattern, typical use of solvents in research laboratories was as unmixed. This makes a sharp contrast to solvent use in factories (or industrial plants) where, e.g., ink for printing or paints for surface treatment contain more than one solvent as liquid components [18, 21, 22]. The patterns of distribution are illustrated for visual understanding in Fig. 1, showing that a combination of 3-6 solvents are often observed in factory air (a thick broken line), in contrast to single solvent use in research laboratories (thin lines). 
Table 6 Laboratories of adequqte and inadequate environment

\begin{tabular}{|c|c|c|c|c|c|}
\hline \multirow[t]{2}{*}{ Research fields } & \multirow[t]{2}{*}{ Total cases $(\%)^{\mathrm{b}}$} & \multicolumn{4}{|c|}{ Administrative control classes ${ }^{\mathrm{a}}$ (no. of cases) } \\
\hline & & Class $1(\%)$ & Class $2(\%)$ & Class $3(\%)$ & Classes $2+3(\%)$ \\
\hline AGR & $594(13.2)$ & $587(98.8)$ & $5(0.8)$ & $2(0.3)$ & $7(1.2)$ \\
\hline BIOL & $664(14.7)$ & $662(99.7)$ & $2(0.3)$ & $0(0.0)$ & $2(0.3)$ \\
\hline MED & $1017(22.5)$ & $1015(99.8)$ & $1(0.1)$ & $1(0.1)$ & $2(0.2)$ \\
\hline SCI & $1089(24.1)$ & $1088(99.9)$ & $1(0.1)$ & $0(0.0)$ & $1(0.1)$ \\
\hline $\mathrm{T} \& \mathrm{E}$ & $1153(25.5)$ & $1133(98.3)$ & $17(1.5)$ & $3(0.3)$ & $20(1.7)$ \\
\hline Other than $T \& E^{d}$ & $3364(74.5)$ & 3352 (99.6) & $9(0.3)$ & $3(0.1)$ & $12(0.4)^{\mathrm{e}}$ \\
\hline Biological $^{\mathrm{f}}$ & $2275(50.4)$ & 2264 (99.5) & $8(0.4)$ & $3(0.1)$ & $11(0.5)^{\mathrm{g}}$ \\
\hline Chemical $^{\mathrm{f}}$ & $2242(49.6)$ & $2221(99.1)$ & $18(0.8)$ & $3(0.1)$ & $21(0.9)^{\mathrm{g}}$ \\
\hline Total & $4517(100.0)$ & 4485 (99.3) & $26(0.6)$ & $6(0.1)$ & $32(0.7)$ \\
\hline
\end{tabular}

a As defined by the Regulation (Ref. 7: for details, see the "Materials and methods"): Class 1, those with adequate environment; Class 2 and Class 3, those with inadequate environment

b $\%$ over total laboratories (i.e., $n=4517$ )

c $\%$ over total laboratories in each field

${ }^{\mathrm{d}} \mathrm{AGR}+\mathrm{BIOL}+\mathrm{MED}+\mathrm{SCI}$

e The difference of AGR + BIOL + MED + SCI from T\&E is significant $(p<0.01)$

${ }^{\mathrm{f}}$ Biological; AGR + BIOL + MED: Chemical; CSI + T\&E

g The difference between the 'Biological' group and the 'Chemical' group is insignificant $(p>0.10)$

The environment in research laboratories (with more than $99 \%$ in Class 1) was generally better than the environment in factories (e.g., $87 \%$ in Class 1 [22]). Nevertheless, the presence of 32 laboratories with Class 2 or Class 3 environments apparently deserves attention. The perusal of individual cases suggests that Class 2 or Class 3 environments were usually in association with use of chloroform in a mobile phase in HPLC. While most part of the analytical system in a HPLC equipment was made leakage-free, the loose connection of the tube (for discharge of the waste mobile liquid phase) with a waste liquid container (usually a large glass bottle) is a source of leaking chloroform vapor. While the fundamental solution might be a development of a chloroform-free mobile phase for HPLC analysis or a move of the HPLC instrument into an exhaust chamber, installation of air suction pipe very close to the leaking point may contribute to reduce the vapor concentration.

Organic solvent use in research laboratories outside of Japan have been reported only on limited occasions. Often, only the fact that workers in laboratories were exposed to organic solvents was mentioned but no further details were given (e.g., Zhu et al. [23]; Zibrowski et al. [24]). Axelsson et al. [5] studied pregnancy outcome of university laboratory employees and reported that the employees were exposed to acetone, benzene, chloroform, dichloroethane, dichloromethane, ethyl alcohol, ethyl ether, methyl alcohol, phenol, petroleum ether and toluene. Taskinen et al. [9] also studied pregnancy outcome of laboratory workers (it was not clear if the laboratories were for research purpose). The solvents used included acetone, acetonitrile, carbon tetrachloride, chloroform, cyclohexane, dichloromethane, ethyl acetate, ethyl alcohol, heptane, isopropyl alcohol, methyl alcohol, petroleum benzine, toluene, 1,1,1-trichloroethane, trichloroethylene, white spirit, and xylenes. Varella et al. [10] reported on mutagenicity of urine of workers in organic chemistry laboratories. Solvents the subjects worked with were diverse, but included acetone, acetonitrile, benzene, dichloromethane, ethyl acetate, ethyl alcohol, hexane and methyl alcohol. Substantial commonalities with present results (Tables 3,4) can be observed in solvent types reported by Axelsson et al. [5], Taskinen et al. [9] and Varella et al. [10], but no data on prevalent use were given in these reports. Thus, it was not possible to make a comparison on use prevalence. In contrast, use of xylenes in histology laboratories were reported by Gunson et al. [6] and Purdie et al. [8], suggesting that xylenes are commonly used in histopathology laboratories in medical fields, as in the present cases (Table 4). In addition, Herpin et al. [7] reported that laboratory technicians in charge of 'anatomy sample preparation for microscopic analysis' were exposed to toluene and ethyl alcohol.

A major limitation of the present analysis is the fact that the target analytes were limited to 47 organic solvents under organic solvent-related regulations ([3, 4, 12]; also see Table 1). Thus, those under separate regulation (e.g., benzene, as previously discussed) or newly coming-up organic solvents (such as 1-bromopropane, a surrogate for 2-bromopropane, as 2-bromopropane has a potent toxic effects on reproductive systems both in men and women 
[25]) were not taken into consideration. Secondly, all research institutions visited in this survey were large in size. Although the work environments surveyed were generally good, it is not clear if this conclusion can also be applied to small-sized research institutions. Scale-dependent difference in work environments may exist among research institutions, as observed in production factories [26]. Another limitation is short-term and changing nature of research activities. Quite different from production workplaces, the activities in a research laboratory are generally for a short time period. For example, one series of HPLC analyses may be terminated within a few hours, and may not be repeated on the next day, although the exposure to xylenes in a histology department in a clinical facility may be repeated almost day-by-day as far as clinical activities continue. The strategy of the present survey could not take such changing exposure into consideration.

In conclusions, survey in large research institutions revealed that only 26 types out of 47 legally designated organic solvents were commonly used in research laboratories. In the large research institutions, the work environments in more than $99 \%$ of research laboratories were adequately controlled. Nevertheless, the environments with leakage of chloroform vapor from HPLC facilities remained yet to be improved.

Acknowledgments Thanks are due to the administration and the staff of Kyoto Industrial Health Association for their interest in and support to this work.

Conflicts of interest The authors declare that they have no conflicts of interest.

\section{References}

1. Ministry of Health, Labour and Welfare, Japan. Industrial Safety and Health Law (in Japanese) (Law No. 25; originally enacted in 1972 as Law No. 57). Tokyo, Japan. 2006.

2. Ministry of Health, Labour and Welfare, Japan. Enforcement Order of Industrial Safety and Health Law (in Japanese) (Cabinet Order No. 72, originally enacted in 1972 as Cabinet Order No. 318). Tokyo, Japan. 2006.

3. Ministry of Health, Labour and Welfare, Japan. Work Environment Measurement Standards (in Japanese) (Ministry of Health, Labour and Welfare Notification No. 44; originally enacted in 1976 as Ministry of Health, Labour and Welfare Notification No. 46). Tokyo, Japan. 2006.

4. Ministry of Health, Labour and Welfare, Japan. Work Environment Evaluation Standards (in Japanese) (Ministry of Health, Labour and Welfare Notification No. 50; originally enacted in 1988 as Ministry of Health, Labour and Welfare Notification No. 79). Tokyo, Japan. 2006.

5. Axelsson G, Lütz C, Rylander R. Exposure to solvents and outcome of pregnancy in university laboratory employees. Br J Ind Med. 1984;41:305-12.

6. Gunson TH, Smith HR, Vinciullo C. Assessment and management of chemical exposure in the Mohs laboratory. Dermatol Surg. 2011;37:1-9.
7. Herpin G, Gauchard GC, Vouriot A, Bannhart B, Barot A, Mur $\mathrm{J}-\mathrm{M}$, et al. Impaired neuromotor functions in hospital laboratory workers exposed to low levels of organic solvents. Neurotox Res. 2008;13:185-96.

8. Purdie GL, Purdie DJ, Harrison AA. Raynaud's phenomenon in medical laboratory workers who work with solvents. J Rheumatol. 2011;38:1940-6.

9. Taskinen H, Kyyrönen P, Hemminki K, Holkkala M, Lajunen K, Lindholm M-L. Laboratory work and pregnancy outcome. J Occup Med. 1994;36:311-9.

10. Varella SD, Rampazo RA, Varanda EA. Uninary mutagenicity in chemical laboratory workers exposed to solvents. J Occup Health. 2008;50:415-22.

11. Nagasawa Y, Ukai U, Okamoto S, Samoto H, Itoh K, Moriguchi $\mathrm{J}$, et al. Organic solvent use in research institutions in Japan. Ind Health. 2011;49:421-6.

12. Ministry of Health, Labour and Welfare, Japan. Ordinance for Prevention of Organic Solvent Poisoning (in Japanese) (Ministry of Health, Labour and Welfare Ordinance No. 1; originally enacted in 1972 as Ministry of Labour Ordinance No. 36). Tokyo, Japan. 2006.

13. Ministry of Health, Labour and Welfare, Japan. Ordinance for Prevention of Health Effects due to Exposure to Designated Chemicals (in Japanese). (Ministry of Health, Labour and Welfare Ordinance No. 158; originally enacted in 1972 as Ministry of Labour Ordinance No. 39). Tokyo, Japan. 2001.

14. Aksoy M. Benzene as a leukemogenic and carcinogenic agent. Am J Ind Med. 1985;8:9-20.

15. International Agency for Research on Cancer. Benzene. IARC Monogr Eval Carcinog Risk Chem Hum. 1974;7:203-21.

16. International Agency for Research on Cancer. Benzene. IARC Monogr Eval Carcinog Risk Chem Hum. 1982;29:93-148.

17. International Agency for Research on Cancer. Benzene. IARC Monogr Eval Carcinog Risk Hum. 1987;Suppl. 7:120-2.

18. Samoto S, Fukui Y, Ukai H, Okamoto S, Takada S, Ohashi F, et al. Field survey on types of organic solvents used in enterprises of various sizes. Int Arch Occup Environ Health. 2006;79:558-67.

19. Ministry of Health, Labour and Welfare, Japan. Work Environment Measurement Law (in Japanese) (Law No. 74; originally enacted in 1975 as Law No. 28). Tokyo, Japan. 2011.

20. Japan Association for Working Environment Measurement. Working Environment Measurement System in Japan. 3rd ed. (in Japanese). Japan Association for Working Environment Measurement, Tokyo, Japan. 1996.

21. Ukai H, Inui S, Takada S, Dendo J, Ogawa J, Isobe K, et al. Types of solvents used in small- to medium-scale industries in Japan; a nationwide field survey. Int Arch Occup Environ Health. 1997;70:385-92.

22. Nagasawa Y, Ukai U, Okamoto S, Samoto H, Itoh K, Moriguchi $\mathrm{J}$, et al. Organic solvent use in enterprises in Japan. Ind Health. 2011;49:534-41.

23. Zhu JL, Knudsen LE, Andersen A-MN, Hjollund NH, Olsen J. Laboratory work and pregnancy outcomes; a study within the National Birth Cohort in Denmark. Occup Environ Med. 2006;63:53-8.

24. Zibrowski EM, Robertson JM. Olfactory sensitivity in medical laboratory workers occupationally exposed to organic solvent mixtures. Occup Med. 2006;56:51-4.

25. Kim Y, Jung K, Hwang T, Jung G, Kim H, Park J, et al. Hematopoietic and reproductive hazards of Korean electronic workers exposed to solvents containing 2-bromopropane. Scand J Work Environ Health. 1996;22:387-91.

26. Ukai H, Ohashi F, Samoto H, Fukui Y, Okamoto S, Moriguchi J, Ezaki T, Takada S, Ikeda M. Relation of average and highest solvent vapor concentrations in workplaces in small to medium enterprises and large enterprises. Ind Health. 2006;44:267-73. 